\title{
LECTURER PERFORMANCES IN INDONESIA HIGHER EDUCATION SYSTEM $^{1}$
}

\author{
Elfindri, Supriadi Rustad, Nizam and Dahrulsyah ${ }^{2}$
}

\begin{abstract}
This paper is concern with Indonesia lecturers' performances on teaching and research activities. Particular attention is given to look at teaching and publication performances after a various compensation schemes introduced since 2008. The study began with developing the instruments integrating lecturer's characteristics and academic activities; i.e., including teaching, research, and time allocation. Around 54.000 of lecturers of higher system in Indonesia registered as permanent staffs of universities received certification. The questionnaire forms were digitally filled. This study shows there is a tendency of increase number of working hours of lecturers for teaching process. Publication index is slightly improved after certification and compensation schemes are introduced. Large variations of publication index are observed according to country where doctoral graduate is finished. This study implies that there is a limited improvement of research activities, particularly after the implementation of lecturer compensation policy. This study is ended with a conclusion.
\end{abstract}

Keywords: Lecture Performances, Higher Education, Indonesia.

\section{INTRODUCTION}

Indonesia has a challenge to meet a massive demand for higher education (Hill and Thee Kian Wie, 2012). Approximately 96 of public and 3000 private universities throughout this country operating to serve for more than 4.5 million of students enrolled in higher education (GOI, 2012). The big challenges are to provide lecturers with a certain level of education and to improve the quality of education process and its outcomes (Iskandar and Nizam, 2010).

Since 2008, a new compensation policy for teacher and lecturer is introduced. Lecturers have to participate in certification process, and for whom they are passes, lecturers received additional payment (Jalal, et all. 2009). The motivation to introduce new payment systems of course is to improve incentives, which is hoped

\footnotetext{
${ }^{1}$ This paper is based on data available in higher education system in Indonesia; all expressed here is our responsible. Thanks for Fitriani Yulistiani and Aji Purwinarko who have already involved in building the online data system of Indonesia higher education, as well processing the data deeded for this paper. We also thanks for valuable contributions given by Dewa Suprata, Juprizal, Conny K. Wachjoe, Djoko Kustono, Syamsurizal, dan Sukestiyarno from designing the online data, to improve the usefulness of the data.

2 The first author is professor of Human Resources Economics, Andalas University. Now he is in charge as a secretary of higher education board of Indonesia under research division. Correspondence can be directed to elfindribana@gmail.com. The second author is director of Human Resources of Higher Education in Indonesia. He is a professor of Physics, in University of Semarang, Central Java. The Third author is a secretary of Indonesia higher education board. $\mathrm{He}$ is professor of Civil Engineering, at Gadjahmada University. The fourth author is director of postgraduate education, Bogor Institute of Agriculture, Indonesia.
} 
to influence lecturer performances. This policy is still in question whether after new incentives schemes influences lecturers' performances.

Following to the Indonesian higher educational system, lecturers are assigned to fulfil their three basic tasks; namely teaching, research, and involvement in community actions. Teaching is the main tasks, which is compulsory for every lecturer registered. They are requested to participate in teaching activities for minimum in two subjects per semester (equivalent to 12-16 credit per semester). At the sometime, lecturers are requested to continue their research, aiming to support the content of subject touch, as well as increasing publications for many forms and purposes. Combining teaching and research activities may improve teaching process, and lately it is hope to increase the quality of higher education process.

Efforts to increase the quality of higher education were taken by various form of policy. Besides lecturers were forced to pursue their formal education level, improvement of compensation is also a crucial policy. Since Indonesia lecturers (also teachers) were received salary which is comparably low with lecturers from neighbouring countries, such as Thailand and Malaysia with the similar level of education completion (Filmer and Lindauer, 2001: Jalal et all. 2009). Under a new policy introduced since 2008, teachers and lecturers were targeted to follow certification policy and targeted to achieve universally by the end of 2015 (Jalal, et all. 2009).

The purpose of lecturer certification is to recognize lecturer performance. The valuation was given by peers at the department, and evaluation given by tanned professors to access whether lecturers are eligible to pass certification. For those who are already passed the process of certification, the compensation behind the certification is an extra salary. Furthermore, besides certification, professor lecturers are also given a special support, just to increase the compatibility of professors and their performance as well. Under a new certification schemes, payment for lecturers are automatically increase by $50 \%$ after the certification is passed.

The certification policy and compensation behind the schemes are aimed to reach a certain level of equity and quality in higher education objectives. In the equity side, through certification policy, lecturers are hoped to increase their participation in teaching and research process and encourage them to pursue for doctoral degree. This may attract lecturers to increase their time to spent in campus wide activities, and reducing the in-effective time outside campus. At the sometime, the quality of teaching and learning process in higher education system is believed can be gradually improved.

The question is that whether the implementation of lecturer certification results various improvements in the sense of academic achievements. There are at least several results of policy can be seen in terms of how lecturer certification and latter incentives may improve their performances. First, how is the distribution of time for academic activities, under new compensation schemes in higher education system in Indonesia? Second, what are research activities since the introduction of payment incentives?

A limited number of researches available to look at how certification can contribute to various measures, such as lecturer's performances and learning outcomes. Various studies are available in looking the relationships between payments and teacher performances (Levy, 2009; Duflo et al. 2012). Some researchers reported on teacher certification for Indonesia and its impact on performance (World Bank, 2013; Abbas, 2013, Elfindri, 2012). A recent effort to look how compensation influenced the participation rates of teachers in school in India. Since the absence rate of Indian teachers is quite high in an international standard, by introducing compensation has resulted to increase teacher participation in teaching process, also incentives increases learning outcomes of children (Duflo, et al. 2012). Schools which are introduced higher salary are less likely to improve effective class, compared to controlled schools. A similar study is conducted how teachers performance after an incentive for Israeli teacher (Levy, 2009). With applying a random trial method, the study observe that incentives increases teacher performance through preparation of work more intensively, and latter for learning outcomes of the students.

In contrast, in Indonesia context, there is a limited survey to prove the effect of certification on learning outcomes. World Bank (2013) in a recent publication "Spending More or Spending Better: Improving Education Financing in Indonesia, does not support the improvement of teachers incentive system for children learning outcomes in Indonesia. Hafid Abbas (Kompas, 12 June, 2013) "Misteri Pelaksanaan Sertifikasi", were also observe that, in general Abbas fails to look any significant improvement in teachers performance after teacher certificated. He argue, certification is only a matter of administrative tasks, and the process of filing in the instruments were often found to be corrupt. 
Understanding lecturer performances, not only because the certification per see, as a new policy to improve quality of education system in Indonesia, but also we have to look at lecturer characteristics in association with their performances. For example, a larger number of lecturers are pursued their doctoral degree in the domestic university as well as foreign university. Interesting to look how the differences in their performances (i.e., publications) occurred between the differences systems of doctoral education, such as doctoral graduation from US higher education system may be differ from European system, Japanese system, and Indonesia system. So far we have not been able to understand whether under new schemes, with various background of lectures education, there is a tendency to increase performance is still in questions. According to various observations, it is observed that the productivity of scholars may also differ according to the origin country of their post graduate education (Elfindri, 2012).

This research is divided into various sections. The first section is an introduction. Section 2 is a briefly explanation of the data used, to look at Indonesia lecturer performances after certification policy is implemented. Section three discusses the performance of lecturers, following section four examines the characteristics of lecturers according to publication performances. Section five is ended with a conclusion.

\section{INDONESIA LECTURERS ONLINE}

This research is design by using data filled by 54.000 lecturers in Indonesia elsewhere through on line system. This is possible since lecturers has their own national registration number, which is containing name, address, location, education background, etc. All respondents already passed certification process. Questions are related with their teaching activities, research, and various forms of publications. A part from the total respondents, there are 4.800 of lecturers are already assigned as professor. Every lecturer in Indonesia has to fill the questionnaire following online system. When lecturers are able to fill in the data online semesterly, extra salary will automatically been paid. In addition, lecturer with professor level has the additional tasks, besides supervising post-graduate students, they have to publish at least one international publication, and producing one book, and also applying their knowledge to society for three year cycle. Additional incentives are automatically received by professor when they are able to prove through the online system.

At the beginning, the instruments were developed by a tasks team. The pre-tests were applied to make sure any consistency of each questions and it was applied for 5 public universities. Completed pre-tests then the questionnaire was revised and the online system were re-established. Among 54.000 lecturers, there are 52.810 lecturers were participated in the online census process. However, due to error in answering questions and incomplete of some returned questions, the 47.959 lecturers returned the questionnaires with on line system completely ${ }^{3}$.

\section{TEACHING ALLOCATION}

The first question to be answer is how distribution of teaching activities in Indonesia University. According to Indonesia higher education regulation, a lecturer has to in charge in class meeting with approximately 12-16 semester credit semesterly. The rests are for research and non-administrative tasks. When each semester, the teaching allocation can be fulfilled, lecturer will automatically get additional compensations. The distribution of teaching load according to level of lecturer education completed is depicted in Figures 1 below. Figure 1 also shows the distribution of lecturer's time credits according to grade of education, controlled by professorships status. The lowest curves show the time spent for teaching in credit terms for D3 programs, to the highest curves showing the distribution of lecturers in teaching in the post graduate education (Doctoral degree).

Interestingly, the data also show that teaching load is uniquely detected according to level of professorships. Some of professors (8\%) were active teaching in D-3 programme, and some were not involved in teaching for S-3 degree. The credit teaching burdens of professor has a normal curve for S-1 degree, which is following the regulation so far. Implicitly according the Indonesia higher education system, lecturers are assigned to undergraduate education as their main tasks, where for post graduates education teaching is an extra job. With a little bit left skew in the curve of teaching involvement of professors for post graduate

\footnotetext{
${ }^{3}$ There are 4851 lecturers $(9,19 \%$ of the total population) already detected invalid in their online data. The most reasons, inconsistency, incomplete, and others. They are excluded in the analysis.
} 
education. In summary, the data also shows that few of lecturers were teach under capacity, and some others were overload in teaching activities ${ }^{4}$.

Furthermore, in general lecturers in Indonesia have normal distribution of in teaching either professors or non-professor. The data also reveals that the distribution of teaching among lecturers after certification is slightly increased. This is partly due to payment system has encourage lecturers to participate in teaching process significantly.

Figure 1.Teaching distribution According to credits and level of graduates
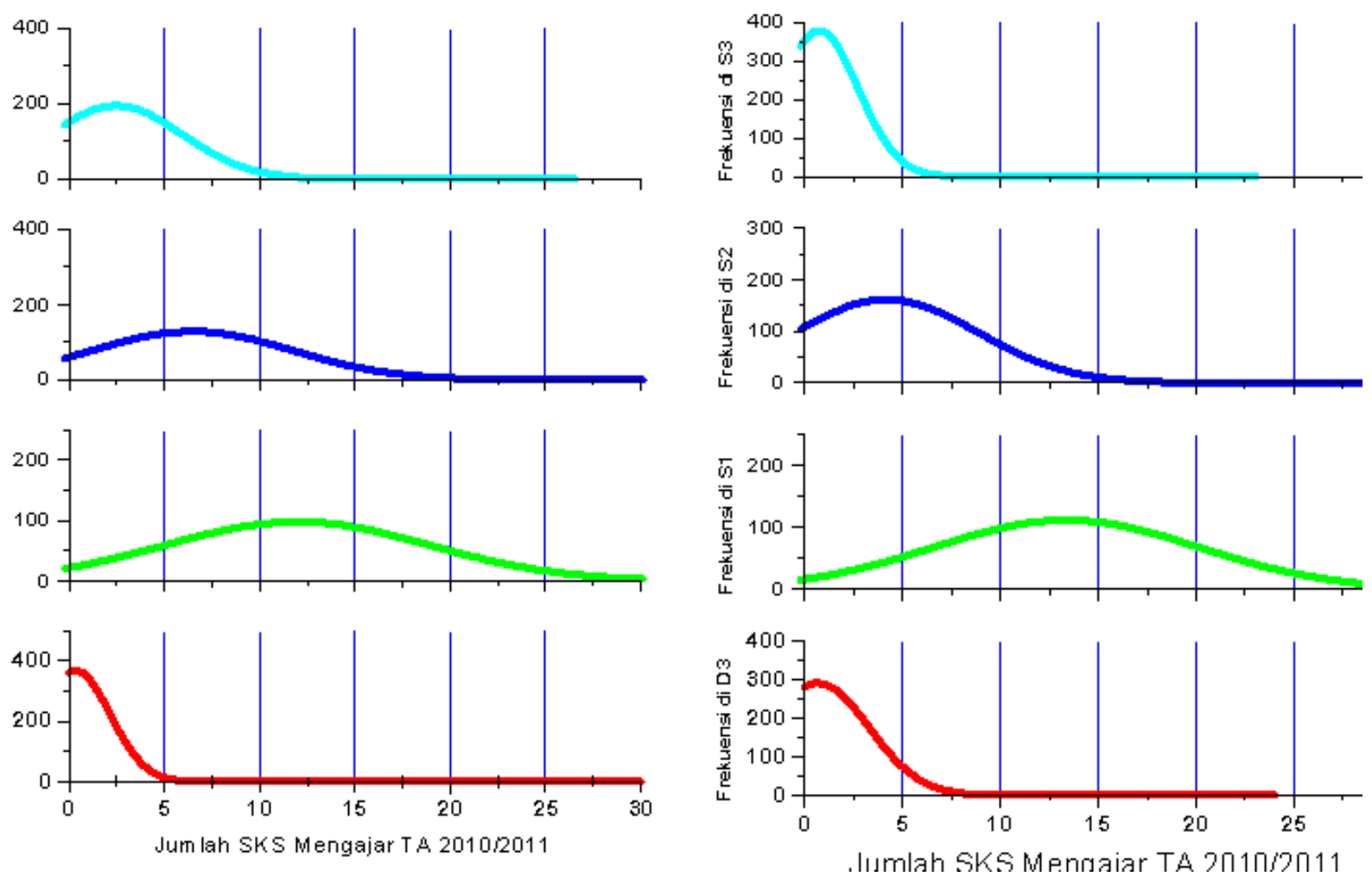

\section{Professor}

Non Professor

The teaching distributions are quite intensive in post graduate education for professors, compared to their counterpart lecturer holder master or doctor qualification. ${ }^{5}$. The influence of existing postgraduate education on teaching is also clearly detected. Fifty seven percent of professors answers the existing postgraduate education in their university and the rest said they do not have post-graduate education in the current university. The problem is if in the department does not run post graduate education, under capacity of lecturers is also observed because some of potential professors could not supervised their students due to unavailability of postgraduate education in their respected university ${ }^{6}$. A study conducted by Allgood and Walstad (2013) observed that incentives matter for teaching and research.

${ }^{4}$ According to Indonesia higher education regulation (chapter 17, 2013) lecturers are assigned differ according to level of education completed. Professors are having $35 \%$ of their time for teaching and $45 \%$ for research activities in contrast for beginning lecturer their teaching load is approximately $45 \%$.

${ }^{5}$ Demand for teaching in post-graduate education is somehow large due to a high demand of post graduate education. Due to limited number of lecturers in Indonesia are able to complete their Ph.D. degree, the postgraduate education is limited operating available.

${ }^{6}$ The availability of lecturers in Indonesia provides some insights that Indonesia actually potentials to enlarge their post graduate education. Since 2013, Doctoral education schemes is introduced to optimize the existing under capacity of lecturers, see Elfindri et. all. (2012) on his reporting on Doctoral Education in Indonesia; unpublished report. 


\section{PUBLICATIONS}

We measure publications as a part of lecturer performance beside the teaching allocation. Here there are various publications available, starting from local unaccredited journals to international accredited journals. The following analysis shows how the trend in publication index after certification is introduced since 2008. We use international and national publication index reported by lectures as an indicator of lecturer productivity in research. Based on 3 year recall $(2009,2010$, and 2011), and publication index is shown according to level of lecturer status and involvement in public and private universities as in Table 1.

In general, publications of journals of Indonesia lecturer is far behind compared to publications by lecturers from others Southeast countries, including the citation index. This evidence partly explained by the higher education structures, as well as lower investment in research in Indonesia. From the current data also reveals that publication of research in Indonesia is slightly increase since lecturer compensation schemes is introduced. A various publication media are available, starting from the low quality publication journals, national accreditation journals to international publications recorded in international citation, such as Scopus and Thomson.

The data shows that publications were dominantly in local unaccredited journals compared to national or international accreditation journals. A large variation of publication index exists between lecturers according to their current grade and the origin of their university assignments (general versus private). The publication indexes in local journals are of the most choices since the implementation of certification. There is no serious different among young and professors status. The publications for local unaccredited journals range from $23 \%$ in 2009 to $36 \% 2011$ for assistances, and a stable index for professors.

In $2009,15 \%$ of professor from public universities has published their research in international reputation journals and it increases to $26 \%$ in 2011 . Implicitly, publications are increased by $11 \%$ point since the implementation of double payment system for professor. Professor received their normal salary and extra payment due to certification and professorships supports. However, the trend of publication of non-professor lecturers in public universities is only slightly improvements. The publication index raises from $4 \% 2009$ to 7 $8 \%$. International publications index for private lecturer even lower, for all levels of lecturer status.

Table 1: Index of Publication a/ According to Types of Journal and

Level of Lecturer Assignment

\begin{tabular}{|c|c|c|c|c|c|}
\hline & \multirow[b]{2}{*}{ Year } & \multicolumn{4}{|c|}{ Lecturer Assignments } \\
\hline & & Assistance & Junior Lector & Senior Lector & Professor \\
\hline \multicolumn{6}{|l|}{$\begin{array}{l}\text { Lecturer from } \\
\text { Public University }\end{array}$} \\
\hline \multirow{3}{*}{$\begin{array}{l}\text { National } \\
\text { Unaccreditation }\end{array}$} & 2009 & 0.23 & 0.35 & 0.37 & 0.35 \\
\hline & 2010 & 0.31 & 0.42 & 0.40 & 0.36 \\
\hline & 2011 & 0.36 & 0.38 & 0.35 & 0.35 \\
\hline \multirow{3}{*}{$\begin{array}{l}\text { National } \\
\text { Accreditation }\end{array}$} & 2009 & 0.04 & 0.07 & 0.10 & 0.29 \\
\hline & 2010 & 0.06 & 0.09 & 0.11 & 0.32 \\
\hline & 2011 & 0.05 & 0.09 & 0.10 & 0.26 \\
\hline \multirow{3}{*}{$\begin{array}{l}\text { International } \\
\text { Journal }\end{array}$} & 2009 & 0.05 & 0.04 & 0.04 & 0.15 \\
\hline & 2010 & 0.06 & 0.06 & 0.05 & 0.19 \\
\hline & 2011 & 0.08 & 0.07 & 0.07 & 0.26 \\
\hline \multicolumn{6}{|l|}{$\begin{array}{l}\text { Lecturer from } \\
\text { Private University }\end{array}$} \\
\hline \multirow{3}{*}{$\begin{array}{l}\text { National } \\
\text { Unaccreditation }\end{array}$} & 2009 & 0.32 & 0.37 & 0.40 & 0.47 \\
\hline & 2010 & 0.36 & 0.41 & 0.45 & 0.45 \\
\hline & 2011 & 0.36 & 0.40 & 0.43 & 0.45 \\
\hline \multirow{3}{*}{$\begin{array}{l}\text { National } \\
\text { Accreditation }\end{array}$} & 2009 & 0.01 & 0.05 & 0.06 & 0.18 \\
\hline & 2010 & 0.04 & 0.05 & 0.06 & 0.10 \\
\hline & 2011 & 0.03 & 0.05 & 0.07 & 0.12 \\
\hline \multirow{3}{*}{$\begin{array}{l}\text { International } \\
\text { Publication }\end{array}$} & 2009 & 0.01 & 0.02 & 0.02 & 0.04 \\
\hline & 2010 & 0.03 & 0.02 & 0.02 & 0.03 \\
\hline & 2011 & 0.04 & 0,03 & 0.03 & 0.09 \\
\hline
\end{tabular}

Note: a/ Index of publication is measured total number of publication divided with number of lecturer 
The publications for the local accredited journals are only slightly increased. A relative limited publication of lecturers in national journals accredited due to the limited and unorganized number of journals have been available and discussed elsewhere (Tery Mart, Kompas, 2013). The survival rate of local journals was also as a factor, contributed to explain the limited publications. An intensive discussion in national media about the growth of predator journals, where the journals grow significantly, without having any quality controls (Tery Mart, Kompas, 2013)

If we compare between institutions status, public versus private universities where lecturer assigned, even in general publication index is too low to compare with others publications of lecturers elsewhere, the situation of lecturer productivity in private universities is much worse. Where their productivity of publication in international journal were from 1-4\% in 2009 and slightly increase in 201 becomes around 3-4\%, except for professor the increase was a quite significant becomes $9 \%$ in 2011. Either lecturers in public universities or in private universities, the publications still using unaccredited journals as their choices. Some argue that private universities much serious in terms of quality achievements, partly as consequences of the existing problems in recruitments of lecturers, as well as their level of academic achievements (Elfindri, Kompas, 2012).

But to some extend the other factors may contribute largely to the research performances of doctoral degree, even after the implementation of new payment system (Allgood and Walstad, 2013). Besides teaching burden may seriously increases, the administrative involvement of lecturers may results a serious time to organize. For example, our data show that $48,5 \%$ of lecturers (non professors) are involved in administrative tasks and $68,9 \%$ of professors were reported involved in administrative tasks.

Our findings consistent with the distribution of teaching load of lecturer according to level of lecturer status where allocation for teaching are more likely higher for lower grade lecturer compare to professors' holder. So incentive behind professor and certification encouraged lecturers in participating research is only limited its impact on performances. As Purwanto (Opini Kompas, 2011) stated that incentives model is good for lecturer with international publication.

Figure 2: Trends in Publication According to Duration of Ph.D Completion

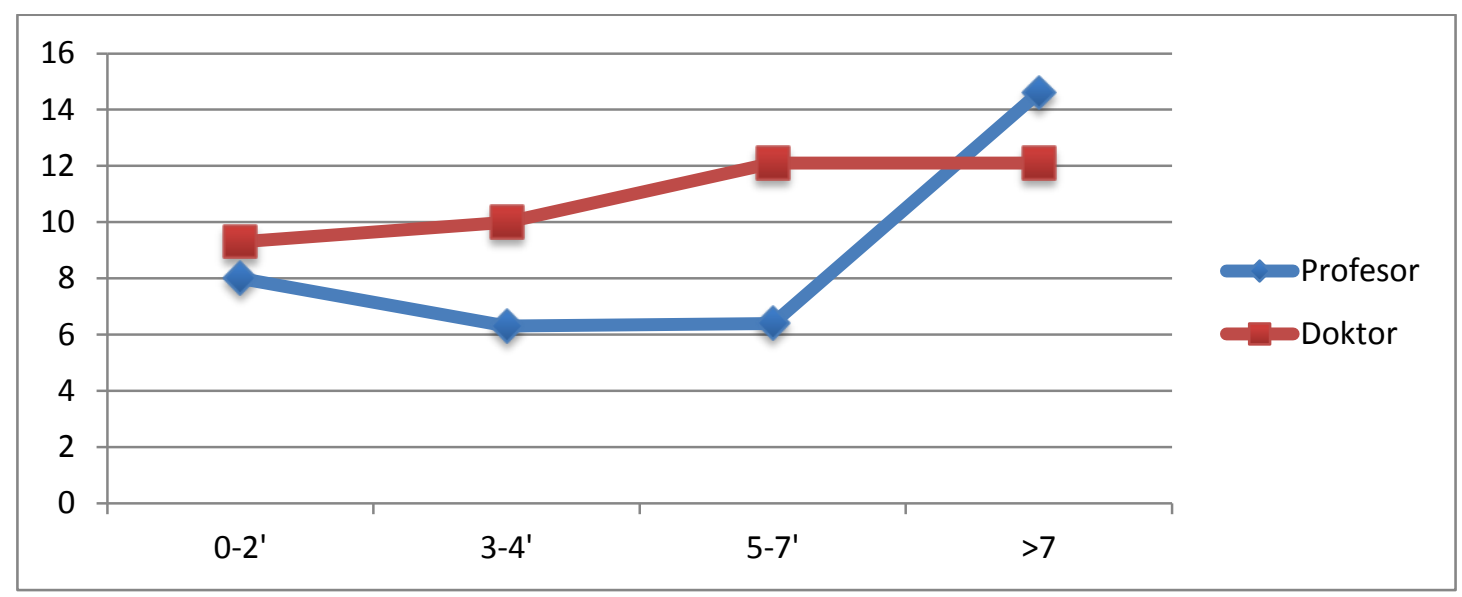

How we explain the evidence where the publications as a good indicator of academic achievements of lecturers? One way is to look timing of the Indonesian lectures publication index is depicted in Figure 2. The most common issue is the lower productivity of Indonesian lecturers due to their environmental atmosphere, which has not been always with conducive with environmental conditions. Our data reveals that there is no clear figures, since the trend of publications were slightly increases when the return periods after completion of doctoral education much longer. Doctoral holder tended to increases their publications may be due to large variations of compensation between Professors and Doctoral holders. The increase in professor publication index after 7 years or more was partly due to regulations. Without any publication, the compensation will be ended that let professor publish their research in international journals. A recent study conducted by Stock and Siegfried (2013) found that an advantage of PhD dissertation format for publication has let the productivity of publication much higher after completion of Ph.D., and publications were strongly correlated with academic profession jobs. In This study we have not been able to detect whether publications come from dissertation, or continuing their previous research consistently. 


\subsection{Publication Trends and the Origin of Alumni}

One of the important outcomes of this analysis is that we can observe how publication of lecturers according to the university were Doctoral holder level was obtained. Since a huge number of Indonesia lecturers has completed their postgraduate education from overseas universities. Each university has its own system and core values, and such system and core value could contributed differently in terms of their academic contributions. Since the costs of completing doctoral degree are substantially higher in developed countries, the comparable costs to results after the candidate returning to Indonesia are also significant issues in higher education policy.

For example, in sending one students for Doctoral degree to USA University, the costs are approximately 7-8 times higher compared to those who follow Doctoral degree in Natives University (Elfindri et all. 2012). If the costs relatively higher for sending lecturers to developed Countries University, then is there any significant difference in their publications? Figure 3 shows the publication index according to places of universities where lecturers graduated. To cover our basic question whether the publication trends exists is also depicted in Figure 3.

Figure 3.Trends in International Publication Index According to Country of Doctoral obtained

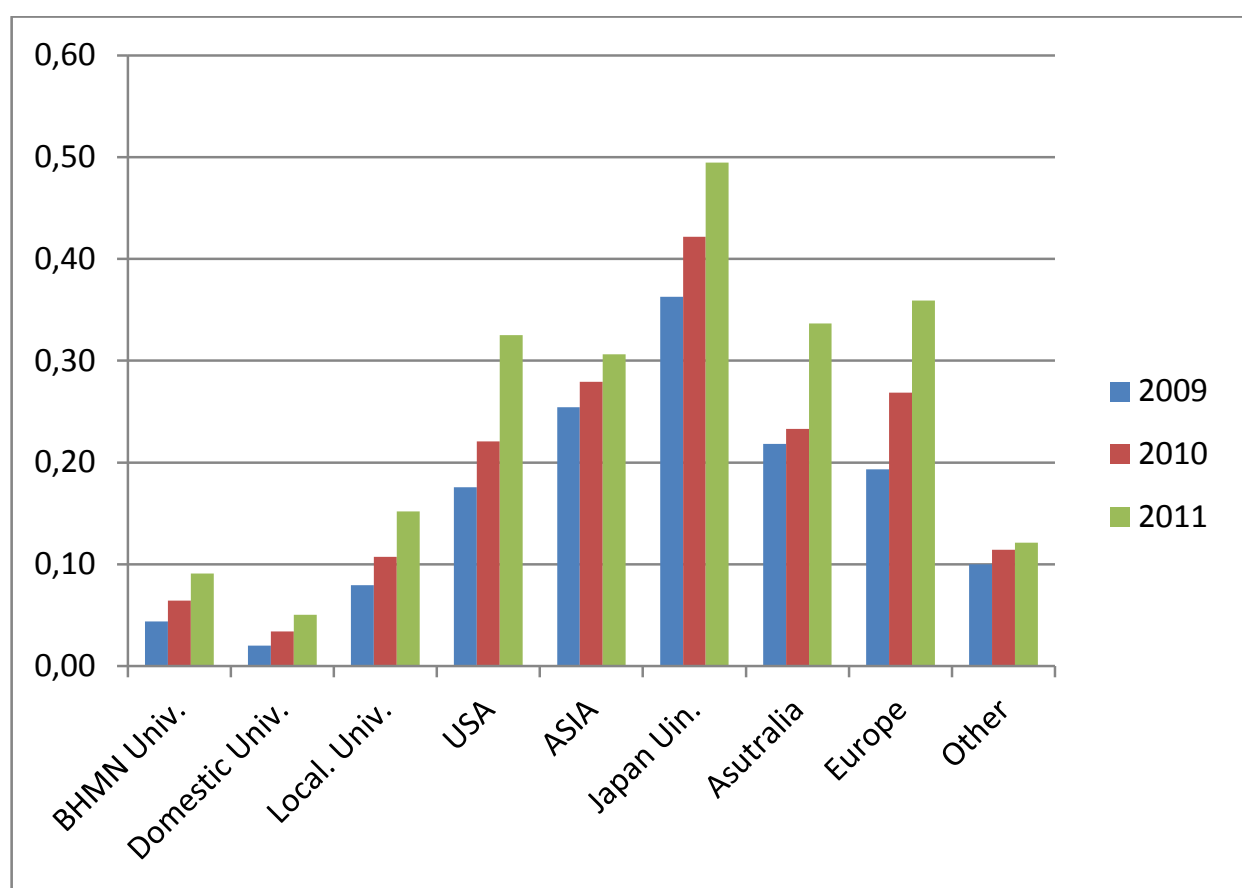

In general, our data reveals that productivity of lecturers of international publication who graduated from foreign university are four to five much higher compared to productivity of lecturers graduated from domestic university. The trends are also significant for the last three year, where new compensation is began. The most productive lectures in terms of international publication are graduated from Japanese University ${ }^{7}$. Their productivity is from $36 \%$ in 2009 to $49 \%$ in 2011 . The second most productive is followed by lecturer graduated from European University, Australia and America. The later origin of graduates can contribute to international journals $32-33 \%$ in 2011.

The performance of lecturers who graduated from local universities are far below than those from Japan, European, and American System who are interested in international publications. Even Doctoral graduates from "BHMN" universities, the index is far below. This is may be due to language barriers, since international publications are usually in English. According to various information, Doctoral degree in Japanese university

\footnotetext{
${ }^{7}$ International publication is a main target of doctoral standard in Japanese University. The doctoral students are always involved in laboratory, without any getting courses. In addition, for their alumni, a strong connection between the Japanese university and the university in Indonesia is maintained. Research collaboration is developed between ex-supervisors and with returnee.
} 
put pressures for their doctoral candidate to publish before they are allowing to submit for final doctoral requirement.

In looking the effect of establishment duration after graduates, the selection of sample can be seen in Figure 4. Where for doctoral graduates who have quite long active in Indonesia, 5 years, 7 years and 10 years and more after graduation. We compare the index of publications according to country of Doctoral graduates, among Japan, Australia, European University, Asian University, America and domestic university graduates. The figures show that the differentials in publications index become narrow between alumni of overseas graduates and within domestic graduates. In absolute terms, the trend in domestic university alumni produces with a greater number of publications than for those graduated from overseas university ${ }^{8}$.

The similar way in which we can observe how publications in national accredited journals. One may be agree that the ability to publish in national accredited journals is one of another indicator also to avoid the language barriers, and to show any differences in lecturer performance. After completing study, lecturers have to struggle in adapting with their new environment, and some of lectures are often fail to keep continue their research consistently.

Figure 4: International Publication Index Difference Between lecturer graduated from Domestic Universities and Overseas University (2009-2011) Controlled by times of Doctoral completion.

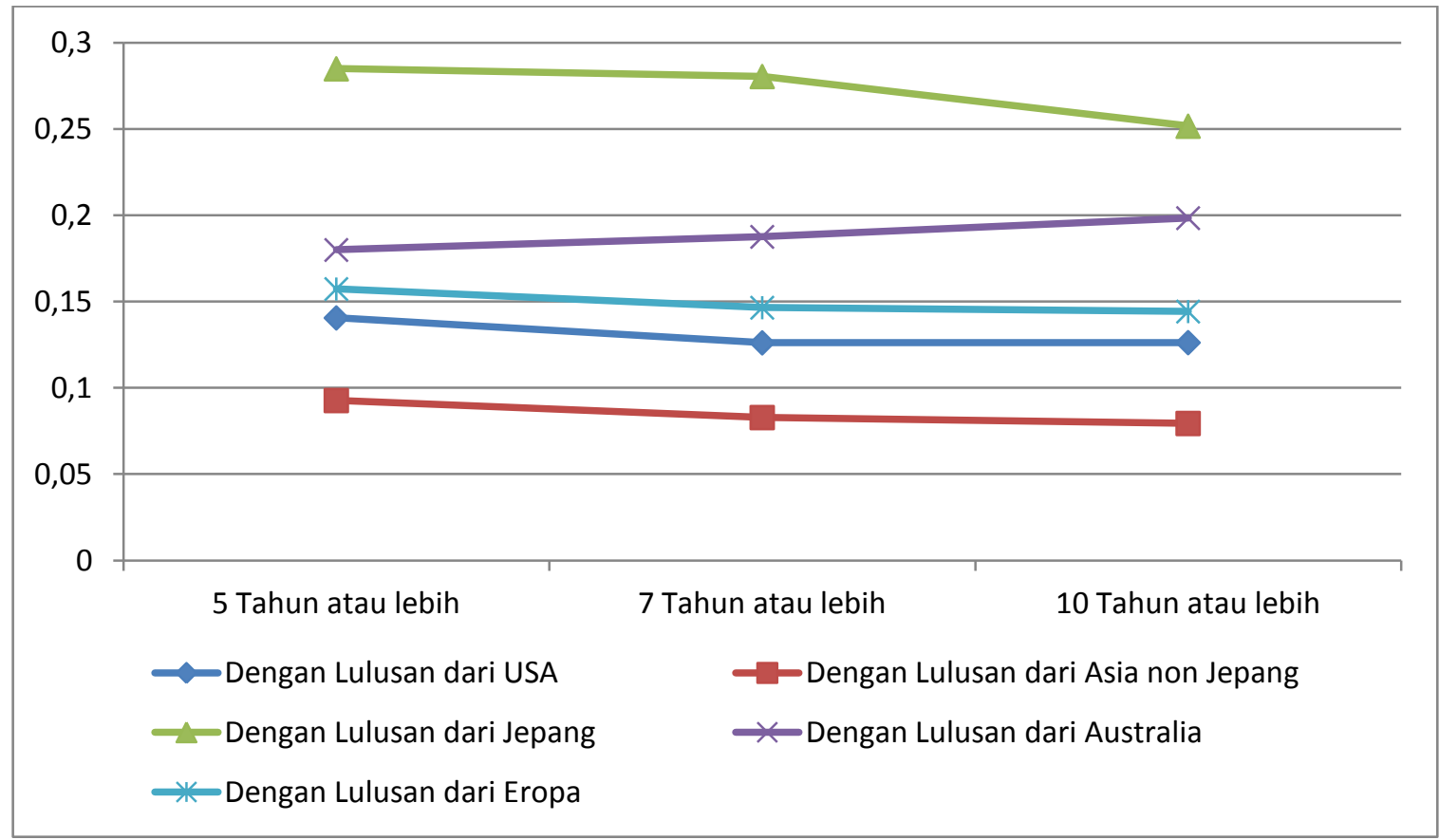

In general, index of publication is only slightly increased from the baseline, although for the first three year of policy is too short to look the policy impacts, at least the growth of publications only slightly increased. Lecturers graduated from Japanese university are consistently produce publications, either in international or in national journals. There are 27\% in 2009 and increased to 33\%, which was around 5\% points increased. The second productive alumni were graduated from European system, like form Australia and European University. The index of publication increased from beyond $20 \%$ in 2009 to $25 \%$ in 2011 , followed by USA alumni at the same period, form $20 \%$ to $25 \%$.

The publication of lecturers graduated form their own university is not as bad as what have been already discussed. It is shown that the publication index increased around 5\% points, form $18 \%$ in 2009 to $25 \% 2011$ respectively. The productivity of those graduated from own university were much better than those graduated from Asia University (excluding Japan) and domestic university elsewhere. It is not easy to explain these figures, although some believe that externalities can be gained by lecturers who gradated form their own university.

8 It is recognize that the data representing individual level analysis, which is also be explained by the individual capacity and its choices. The need to understand how the differences are occurs. 
Figure 5. Average Publications of lecturer in National Journal and the Origin of Alumni

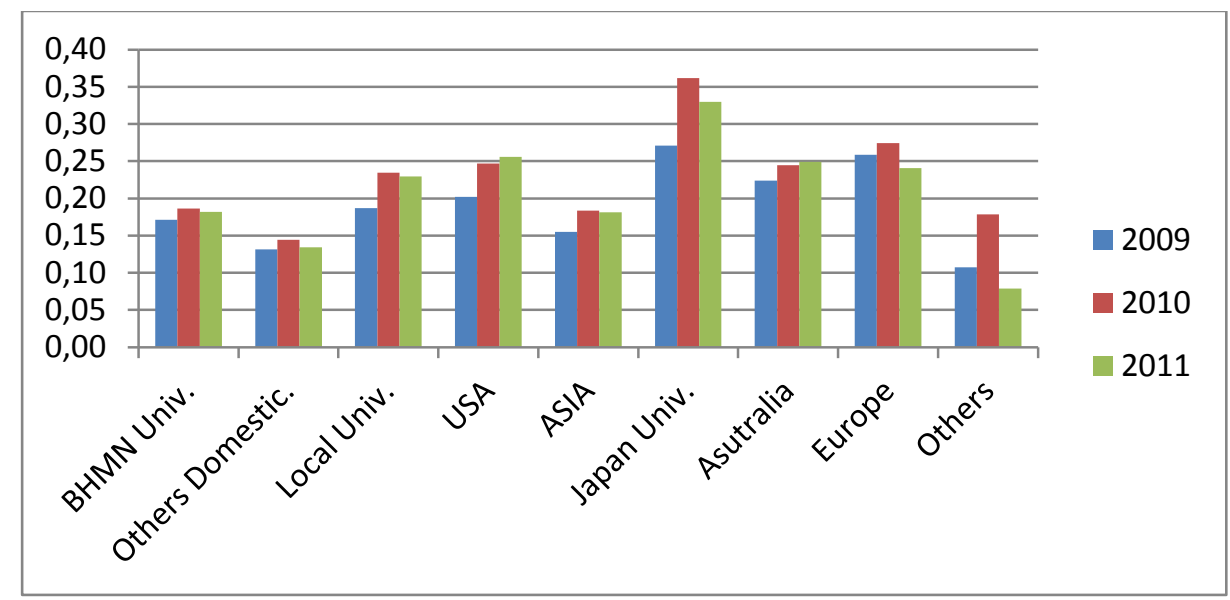

The most interesting findings are that the limited growth of publication of Indonesia lecturers in national journals can be explained from various factors. It is probably that most of good quality researches are intended to send to any international publications, consequently there is a limited number of paper submitted into national journals. There is another possible factor where local journal are not easy available, with their periodical publication is often interrupted and discontinued.

\subsection{BOOK PUBLICATION}

Beside publications in international journals, another indicator may be useful to look any improvement in publications which can be look from book published by lecturers. According to definition, published books can be recorded in our analysis whenever books have already has the international number catalogue and sells in the public bookstores. They are classifies as monographs, references, text-book, and popular books.

Figure 6 shows that the trends in books written by Indonesia lecturers are slightly increase since the introduction of certification, as well as additional payment system. As one may be agree, books are written and often produced by professor compared to non-professor lecturers. Around $25 \%$ of professor in Indonesia produced books for at least since the data is collected. $22 \%$ of lecturers in public universities were ever published books and increased to $26 \%$. Lectures in private universities are more likely productive in writing books, where around $35 \%$ of private higher lecturer reporting ever write book. The lower the grade of lecturer the lower book is published.

Figure 6. Book published with catalogue number according to level of lecturer grades, and place of involvement (2009-2011)

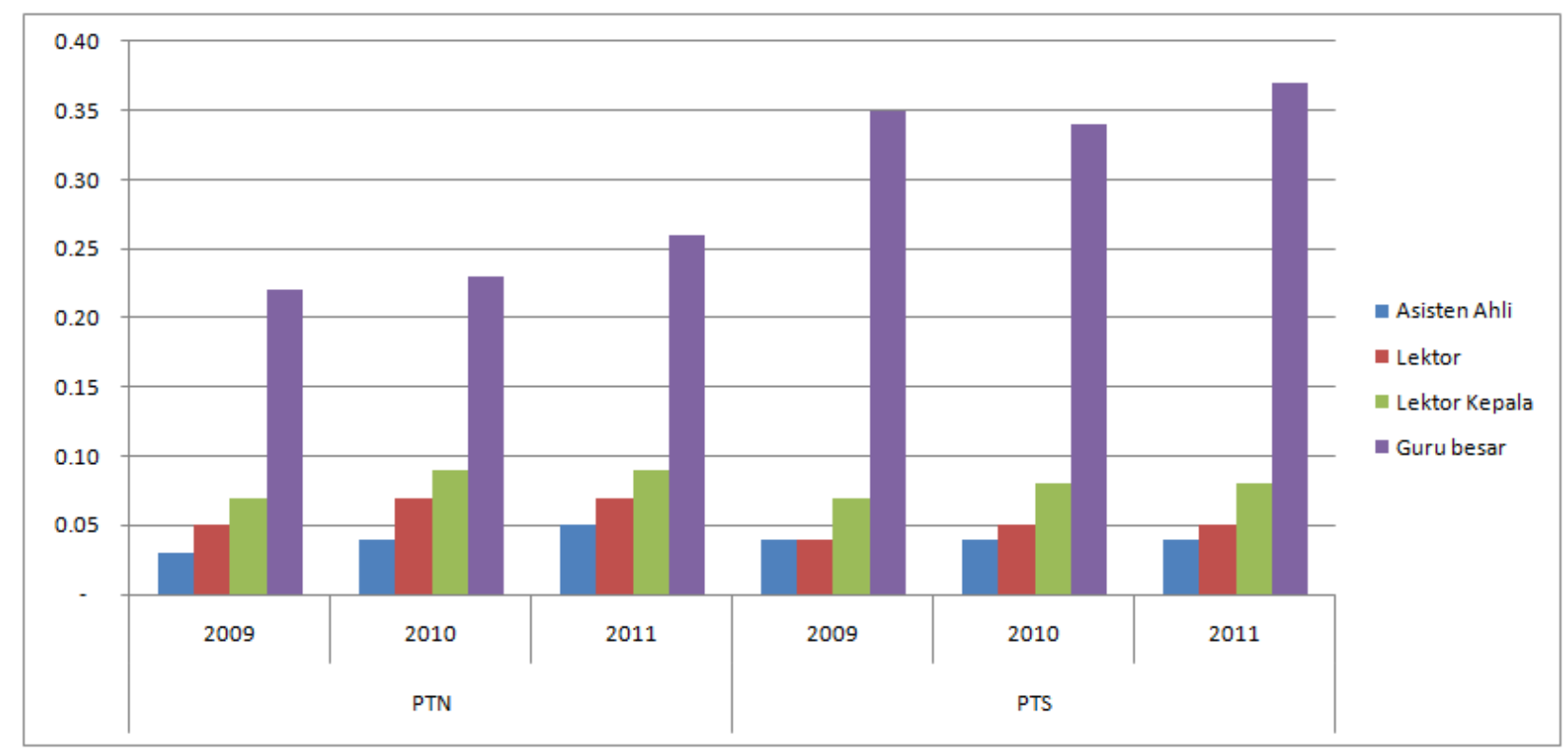


Like in the previous section, writing book is an alternative way to access lecturer publications. It is become clear however that slightly improvements in either journals or books published since the introduction of lecturer compensation schemes in Indonesia higher education system. Figures 7 also continue to look how is books published by lecturers according to time and the country origin of graduates.

In contrast with international publications, Indonesia lecturers are produces books with quite improvements and much higher compared to alumni from Japanese university. When the academic journals are noncomparable between Indonesian lecturer and other developed countries, the productivity of lecturers are distinctly according to the country origin of graduated. Lecturers graduated from domestic university produce books are quite similar compared to those graduated from foreign universities. An improvement in book publication since compensation is by $5 \%$ points. The most productive lecturer in terms of writing books were from Australian graduates, and second from Domestic graduates. Due to Japanese Alumni are more productive in journals, for books they are the lowest among others. When publication is gauged as an alternative to look lecturer productivity in research, the question why the trend of both journals and books is far behind than those lecturers in developed universities, are still unclear.

Figure 7. Book Published According to Country University Where Doctoral Completed

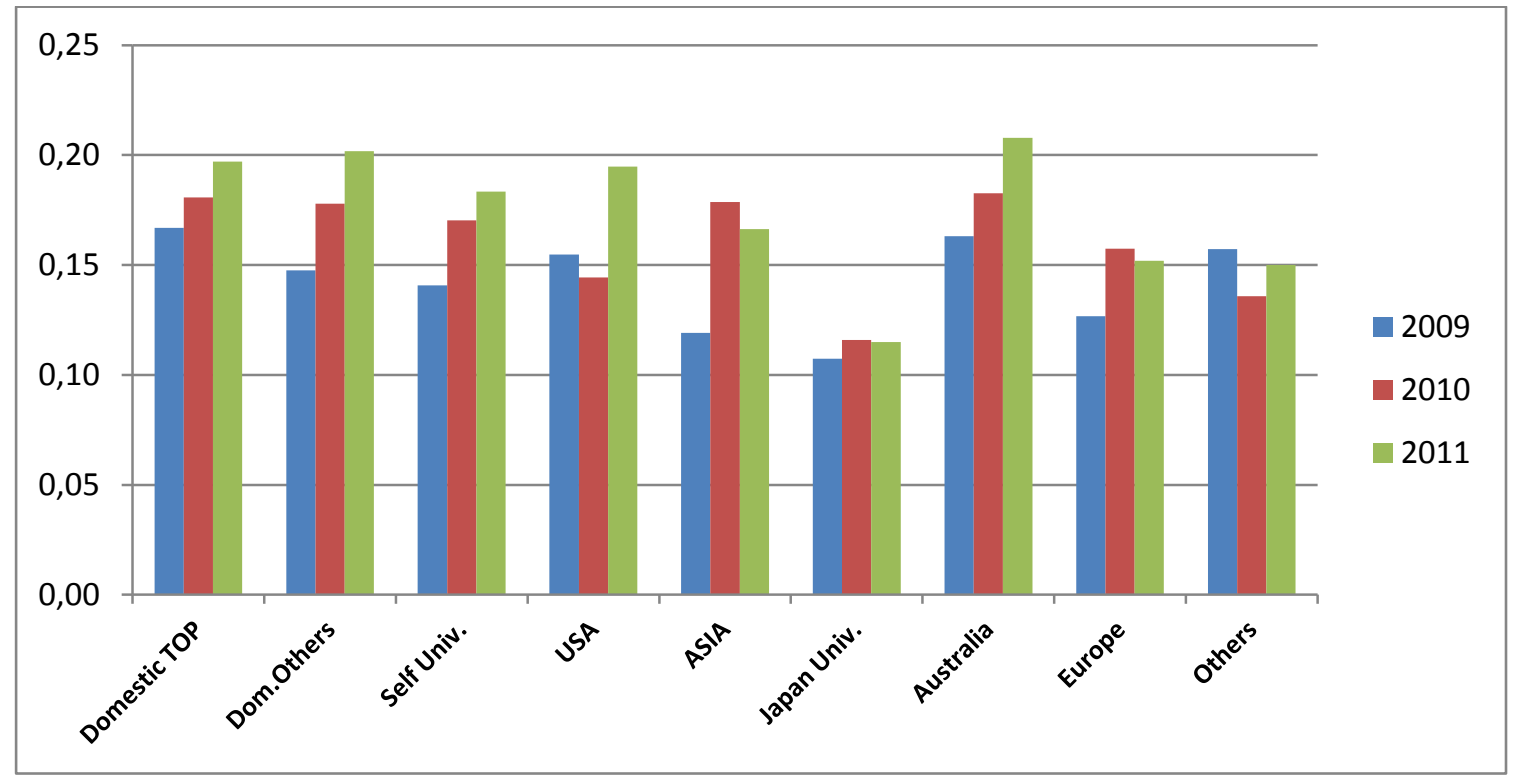

\section{CONCLUSION}

This paper is aimed to look at how the lecturers' performance after the introduction of new compensation schemes in higher education system in Indonesia. Various study in lower level education concluded that payment incentives for teachers has increased the participation of teacher in the schools and improve learning outcomes. The mechanisms were through improvement in class effectiveness; reduce absence of teachers, and students learning outcomes. For higher education in Indonesia, this issue is relevant since a new payment system introduced in Indonesia. Teaching allocation and publications are measured as lecturer performances.

The data confirm that after certification and a new compensation schemes are implemented, lecturer performances are a quite unique. There is a tendency of increased in participation of lecturers in Indonesia for teaching activities, even also for administrative tasks. The publication index is slightly increased, although the trends vary from level of lecturer grades, and country of doctoral degree obtained. The productivity of professors are significant higher compared to others counterparts. But in general, international publication of lower graded lecturer is much lower which is needed to be analyzed further.

Indonesia lecturers who graduated from Japanese university have the highest publication indexes in international journals compared to elsewhere graduate. But their productivity in terms of books are the lowest. Lecturers graduated from domestic university are far behind the productivity in terms of journals, but they are producing books are much higher. 
The limitation of this paper is that the lecturer performances are measured through publication and time allocation for teaching. There is also interesting to learn, how the education process can contribute to increase the quality of higher education which is not study in the current paper.

\section{REFERENCE LIST}

Abbas, Hafid (2013) "Misteri Pelaksanaan Sertifikasi Guru”, Opini Kompas, Wednesday, 12 June, 2013.

Allgood, S. and William B. Walstad (2013) "How economists Allocate Time for Teaching and Research", AER: Paper and preceeding, 103(3), 654-658.

Barrie, Simon, C. (2012) "A research-based approach to generic graduate attributes policy" Higher Education Research \& Development, Vol. 31, No. 1, February 2012, 79-92

Elfindri dkk. (2012) "Pengembangan Program Pascasarjana", laporan Direktorat Ketenagaan, Dikti-Jakarta.

Elfindri (2012) "Evaluasi Kinerja Publikasi Dosen Indonesia”, Draft untuk Direktorat Pendidikan Tinggi.

Elfindri (2013) 'Optimalisasi Sertfikasi”, Opini Kompas.

Filmer, D. and David L.Lindauer (2001) "Dose Indonesia Have a "low Pay" civil Services?, BIES 37(2), 189206.

Hill, Hal and Thee Kian Wie (2012) "Indonesia Universities in Transition: Catching up and Opening Up", BIES 48(2), 229-252.

Iskandar, $\mathrm{H}$ and Nizam (2010) "A Strategic Assessment of the Higher Education Sector in Indonesia", report presented to higher education, Ministry of Education, Republic of Indonesia.

Jalal, Fasli, Muchlas Samani, Mae Chu Chang, Ritchie Stevenson, Andrew B. Ragatz, and Siwage D. Negara (2009) "Teacher Certification in Indonesia: A Strategy for Teacher Quality Improvement", Ministry of Education and The World Bank.

Levy Victor (2009) "Performance Pay and Teacher Efforts Productivity, and Warding Ethics", American Economic Review, 99(5), pp.1979-2011.

Mart, Terry (2013) "Jurnal Predator", Opini Kompas.

Meek,V.Lynn, Ulrich Teichler, Mary-Louise Kearney (eds.) (2009) "Higher education, Research and innovation: Changing Dynamics", Unesco

Podgursky, M.J. and Mathew G.Springer (2007) "Teacher Performance Pay: A Review”, Journal of Policy Analysis and Management, V0I. 26(4). 909-949.

Purwanto, Agus. (2011) "Insentif berbasiskan Publikasi Internasional”, Opini Kompas, 9 November 2011.

Rukmini, Elisabeth (2013) "Rumitnya Jenjang karir Dosen”, Opini Kompas, 2 February, 2013.

Stock, Wendy A. and John J. Siegfried (2013) "One Essay on Dissertaion Formats in Economics", AER and Preceedings 103(3):648-653.

Taylor, E.S. and John H.Tyler (2012) "The Effect of Evaluation on teacher's performance", American Economic Review, 102(7), pp. 3628-3651.

World Bank (2013) 'Spending More or Spending Better: Improving Education Financing in Indonesia', Research Report. 